\title{
Cosmopolitan Ethics, Umma, and Democracy: Between Global Issues and Political Identity Issues In Indonesia
}

\author{
Musa Maliki \\ Dosen FISIP UPNVJ Jakarta \\ Ph.D. Candidate Charles Darwin University, Australia \\ Ahmad Alfajri \\ Dosen FISIP UIN Jakarta
}

\begin{abstract}
Cosmopolitanism is an ideal goal of many contemporary International Relations theories. The main idea conveyed is that our moral obligations as human beings need not be limited by state's boundaries or any other structures. "Citizen of the world" is the main term of this concept. On the other hand, there is also a concept of umma which is termed by many scholars as Islamic community or community of believer. The discussion and comparison between cosmopolitanism and umma is quite rare. Related to that, this paper argues that the Umma and cosmopolitanism are two similar concepts; however they derive from two different civilizations. Democracy in this case is a tool to sustain both the ummah and cosmopolitanism.
\end{abstract}

Keyword: cosmopolitanism, democracy, umma

\section{INTRODUCTION}

When we talk about the concept of cosmopolitanism, the discussion is going to be idealistic because it is all about the transcendental idea, especially, promoted and popularized by Kant. However, recently the discussion of cosmopolitanism is becoming cosmopolitanization. It is popular when it comes to the global risk that is related to the reflexive modernity (second modernity). It is Ulrick Bech who is promoting this concept which is both significant in the debate to tackle the change of the world and contribute to the multidiscipline subject. He is also fostering this concept to be practical when it comes to applied ethics, means cosmopolitan ethics [1].

The term of cosmopolitan ethics is developed, constructed, and adopted in the Western literature (the Greek philosophy to the European philosophy). In fact, it is in line with the Islamic tradition namely the concept of the umma (the belief communities). It is all about matching and sharing the common values and the principles of humanity and justice. In the deep discussion of both concepts, they are in substance have the same purpose/goal (maqasid).

So in this concise article, we are not going to discuss deep theoretical works to compare and contrast between dozens of literature of cosmopolitan ethics and umma, but we will explore more on the discussion of the coherent and cohesive relations between cosmopolitan ethics and umma in the frame of Indonesia democratization as well as how it works practically. Their principles will comprehensively, set a view in the process of democracy in the post-reformation era.

In this article, firstly, we will discuss the concept of cosmopolitan and the umma, and the link between both of them. Second, we will discuss further the challenge of Indonesia as a Democratic Muslim majority country and how the principles of cosmopolitan fit into the umma in Indonesia

\section{COSMOPOLITAN DEMOCRACY AND UMMA WILL BE?}

One of International Relations scholars who introduces and popularizes the concept of cosmopolitan democracy is David Held. In sociology, Beck popularizes the principle of cosmopolitanization. In most Western literature, cosmopolitan concept stems from the Greek philosophy that intermingles with Jewish cosmology. The purpose of this concept is to criticize the social-political crisis in the Athena society, and now it is being used to criticize the social-political crisis in the Western society [2]. We conclude that the point of cosmopolitanism is ideally a concept to bring back universal principle that adopts the civilized citizen of Athena: respect constitution, humanity, justice, peace, harmony, and difference. 
On the other hand, Umma that existed in Madina was guided by the Prophet, Muhammad PBUH for the sake of one-humanity for a better life of citizen within difference, solidarity, responsibility, respect, agreement to live in peace and harmony. It is a moral obligation for human beings to support all these principles. The pluralistic community such as Madina, is a model similar to Athena.

Briefly, the meeting between Muhammad PBUH and his companion from Mecca (muhajir) and Ansar people in Madina created what Islamic scholars called "the Madina Constitution" as a political foundation. What we should note about the immigration of Muhammad was to find freedom and liberation to get peace and justice outside Mecca. The arrival of Muhammad was not to change the culture and custom of Madina and create conflict, but to live together with the universal principle similar to the Athena model.

This constitution was required peace (Islam) in diversity within one-humanity by the act of respect, mutual understanding, inclusive, and civilized manner. Therefore, even though there were many other religions and clans who have not embrace Muhammad's belief system such as Jewish, Christian, and other people, they were living in peace and harmony. Muhammad was respecting, dignifying, and protecting non-Muslims in Madina as long as they also were respecting the Madina constitution. The constitution mentioned the principles of community of belief, humanity, equality, justice, and dignity for all the signatories. For sure, Muhammad was aware of the complexity of all life dimensions (as the different religious, social, and political risks related to his community) in Madina. He always informed his companions to spread peace, feed the hungry, pray while people sleep, kindship ties and shall enter paradise in peace [3].

What we understand in this respect is umma. It is to respect humanity in the pluralistic society. In the light of this sense, umma is in line with cosmopolitan practice with robust interconnection in the principle of belief, human dignity, justice, and respect the difference in the agreement whether it is constituted in local, national or international level. The agreement should be followed and respected with a high commitment to others. Most importantly, the concept of umma is not a label of Islamic community or Islamic political community, but it is a constitutional community of beliefs with the universal principle to witness one another, to compete to do good things and to seize God's will.

\footnotetext{
III. HOW WE SEE COSMOPOLITAN (DEMOCRACY) AND UMMA RELATED TO
}

\section{THE CONTEMPORARY ISSUES IN THE AGE OF TERRORISM CONTEXT AND POLITICAL IDENTITY IN THE DEMOCRACY OF INDONESIA?}

We argue that in the study of International Relations, the concept of cosmopolitan has yet compared seriously with umma. We reckon Shani as an International Relations (IR) scholar who concerns on writing umma. However, by using orientalists' view, he disconnects the texts of umma concepts from the context by neglecting the dialog and contract with non-Muslims. Umma is about embracing other communities by centralizing the universal value of humanity which is dignity, mutual respect and justice in the pluralistic people whether in the local, national or international level[4].

We always need to go back to what Muhammad peace be upon him told the Muslim to spread peace, feed the hungry, pray while people sleep, kindship ties and shall enter paradise in peace in the name of humanity (human soul). This is very relevant and essence to the idea of cosmopolitan ethics to be implemented in the dialog of civilization.

If we would like to take identity in the concept of umma/cosmopolitan, we need to focus on the identity of a universal principle that means to struggle for mutual respect every individual, justice, and consistent to them as well as to be committed. It is because, in umma atmosphere of Muhammad period, there was not identity framework or discourse. It is supported by Heikki Patomaki when he criticizes realism, where it believes strongly in the concept of state, is unitary actor originally begun in 1648 as the Westphalia system: "we do have universal duties to everyone, including foreigners; whereas state moralists deny the wisdom of such universalism"[5].

Moreover, Jonathon W. Moses concludes that umma in the Muhammad era is relevant in principle and its norm in the theory of democratic peace because umma creates an alliance with many community both to create a strong community and some groups would like to be protected by umma [6]. It is important to note that Moses has correctly taken the principles and the values of umma into the contemporary context. Therefore, what we need to do is to improvise the classical tradition and be creative in contextualizing the discourse of the past into the present day.

The five pillar of Islam is only an obligation for the Muslims in umma, not for everyone who is not a Muslim. It is more to the character of the people and how they act in their everyday life with the 
Islam principles, not in the name of Islam identity or emphasize on the ritual, symbolic activities without the act of kindness, respect, dignified different culture, and belief. At that period, there was no modern institution or Islamic institution to express and impose their body of power to force people to follow it. Most importantly was a humble person and trustful person like Muhammad who could ask 'citizen' of Madina and surrounded to make a contract or just to join to live in peace (Islam). We conclude that the concept of identity was unknown in the pre-modern era, therefore taking the context of the epoch and its practice in the past (classical tradition) by finding the principle and values are the most important things than practicing the symbols, the text itself with blinded by the dogmatic mind.

We need to understand in umma is that its practice in the Muhammad era was that the Muslims equally shared mutual respect and understanding with everyone to practice their own culture and belief system and secured by Muhammad peace be upon him with his respect and compassion. Therefore, it was called as dar-al Islam (peace space). It misleads that if someone understands umma in the knowledge that umma consists of only a member of Muslims, for the sake of Muslims and from the Muslims.

Umma at the time of Muhammad was almost in line with cosmopolitan democracy in the sense that they praise highly in humanity, respect and obey the contract (Madina charter) among individual or/and communities within the pluralistic society. In short, the central of concern in umma practice is humanity, mutual respect, and peace (Islam). If today, the political community in the world do not practice these principles and values instead of practices violence intervention in the name of democracy and peace, in fact, they are betraying their democratic constitution principle and values as well as the values of umma and cosmopolitan.

We would like to quote what Moses criticizes the betrayal of their democracy, umma and cosmopolitan in developed countries such as America and its alliance: "liberal democratic states are just as likely to make war (or commit violence) as other types of regimes." Moses also emphasizes his argument by quoting the prominent figure of Democratic peace theory, Doyle: "Liberal states are as aggressive and war-prone as any other form of government or society in their relations with nonliberal states"[6]. It means that the Liberal states such America and its alliance often their governments betray their constitution as their principle and values. They are neglecting their moral principle of their constitution by attaching Vietnam, Afghanistan, Iraq, and others.
The umma/ cosmopolitan/ democracy can enlarge in the basic of universal ethical principle and values, but this will not happen under the threat of coercive act and unilateralism act.

In the process of Indonesia democracy today, the problem of identity is spreading because of the politic of emotion, lack of knowledge, lack of historical understanding, the mentality of the victim, and the desire of truth claim or the sense of superiority to others. The political identity in the new Indonesian democratic system of decentralization is supporting immaturity of a democratic society, creating inhuman behavioural, and far away from the practice of umma in Madina and the cosmopolitan ethics.

It seems, the Indonesian generation today leads to democratize everything. When the elite politics fight between them, they play with the mix of identity, religion, and race issue for the sake of their vested interests. Therefore, Surah al Maidah which was one of the triggers of the issue became blunder due to the democratization of al Qur'an. In another word, this Surah was being instrumentalized and let the populist interpreted democratically, in the setting of elite politics. In short, this issue was being perceived that the interpretation of Surah al Maidah was naturally being humiliated and blasphemed.

In fact, this was a game of political competition among Indonesian elites in the context of governor election and 'test the water' of issuing the next presidential election. Who are the political elites, playing this nasty and superficial politics? They are the generation who like to defend their status quo of interests and in the other side, who want to build new status quo of power by ping-pong the swing people who are not very well educated in the discourse of democracy and applied wrongly about it in their daily life. It is because during Suharto era with his 'fake Pancasila democracy' did not provide enough space for Indonesian citizen to learn (the principles of democracy, especially in the theoretical ways and be applied in everyday life).

In the Ahok case of Christine Chinese governor discrimination and his blasphemy to Islam, there is politics of superficial sameness. Both demonstrators, the anti and pro Ahokers are moved by emotionally desire motive. The slogan "Bela Islam" or "Saya Pancasila," "Saya Indonesia" is a symbol to perform something meaningful and posit strong identity. In fact, they dragged in the heart of consumerism society phenomenon with a tendency of the weak substance of 'marketing,' they would like to pursue people to embrace Islam or becoming nationalist or patriotist, in fact, they 
make fear and insecure (existential treat) for everyone else.

Furthermore, they desirably want to show the 'logo' (outside) as a sign or an attribute to be seen as who he/she is or so-called her/his identity. In fact, they open themselves to be seen as mentally problematic from the very deep of their heart or their spirituality. It shows that this person emotionally frustrated on the something and felt being victimized. In another word, if someone would like to show something from outside, in fact, there is something wrong within (inside) the self. This is the problem of a modern society that has been alienated from the self and trying to seize ontological recognition to the public discourse (social media, demonstration, and so on) in the name of democracy. This phenomenon also happened in America after the tragedy of 11/9. Most Muslims put the logo on his/her chest written: "I am a Muslim." Here we asked, what happen to our Muslim fellow? What is wrong with them? Was that act necessarily to show to the public that he/she are (strong) Muslim? Do we need to portray ourselves as a person who identified as a Muslim with any attributes?

In umma, they know which one is spirituality and which one is emotion and how to manage both of them. Spirituality closes to very deep rationality while emotion is irrational or superficially narrowminded even irrational because the emotion takes over rationality, psychologically [7]. Strong spirituality equals strong rationality and selfconfidence because it needs strong disciple from inside and persistence. The previous big demonstration in Indonesia was playing with emotion, simple mind (superficial), symbol/logo, and formalistic act. This power of populism movements are playing with people emotion, symbol and narrow-minded to act to serve political elites behind the scene. They are emotionally simplistic in dealing with the blasphemy issue while the bigger problem is the disorder of the society or the instability where it goes to the tendency to dar al Harb (space of conflict). This emotionally, formalistic populism movements which are also played by some media were dangerous for the Indonesian democracy because what they act as democracy is not a democracy. In fact, they are betraying the principle of democracy which is rational, non-discrimination, justice, fairness, honest, meaningful and piece. In fact, they also serve elite media that are close to political power while they do the demonstration to be series.

In short, the narrative demonstrations are an illusion of people who presume and perceive themselves as piety Muslims, but in fact, they are trying to avoid the very deep meaning of religion commitments. They think they free, but in fact, they are in the cage of the illusion of freedom because the real freedom is all about spirituality and rationality. These illustration also includes the opposite movement or nationalist movement who against the symbolic Islamic movements.

In umma and most other religious belief systems in the world teach us to control our desire and be discipline to our selves. The more you forgive people you hate the most, the more you free yourself. The more you strive yourself, the more you feel freedom. Freedom is about jihad al nafs. It is about mastering the self to act rationally. Therefore, strong spirituality is always in line with the very deep of rationality in umma. In cosmopolitan and democracy tradition, a deep rationality is one of the important principles to support dialog and achieve peace and maintain harmony. But it will not complete if we do not add intellectual humility to prevent arrogant. Intellectual humility is important to bridge the dialog in the practice of respect, responsibility and shared values and principles.

In contrast to the umma understanding, the populism movement between "Bela Islam" and "Saya Pancasila/Indonesia" are emotionally formalistic in the way they performed their identities. The word of "Allahu Akbar," the socalled white clothes, the act of Jum'atan praying in the middle of the street and other performances are more important than voicing justice, poverty, equality and non-discrimination act where all of these are for the sake of humanity. For them, praying in the public space as political performance is fundamental. In fact, it was only theatrical dramaturgy. Istiqlal was becoming a political arena to perform power than communicate with God, intimately. They want to perform this as they want to be viewed. In the opposite group, saying hastagSaya Pancasila, Saya Indonesia, Sayapenjagake-Bhinnekaan Indonesia, Pekan Pancasila, Pancasila reborn, kenal Pancasila, Pancasila satu, and soon was also a political performance in the name of democracy and symbolic political maneuver that in fact for the sake of power. Both groups of populist movements are crying in the public space for the sake of their perceptions, but in fact, they were being instrumentalized by elite politics. In short, most people in the consumerism society perceives exploiting formalistic emotion is more important than to strive with the heart to be self-discipline, wise, compassion, and forgiving whether insulting the religion and its attributes or national symbols. In fact, all these actions are only instrumentalizing religion and its attribute to legitimate the feel of their accumulative frustration of life and as a sign of lack of confidence in dealing with the 
differences. We conclude that freedom by emotion is illusion and freedom by spirituality is the real freedom. Tariq Ramadan argues: "Our emotions imprison us, but spirituality is both an inspiration and a quest for freedom"[7]. We think if we are going to take the principle of the umma, we need to tackle our problem of emotion and frustration today by educating our self and keep evaluating our education system for the batter democratization.

\section{CONCLUSION}

What we learn from umma, democracy, cosmopolitan are how we can capture the principle of the context in the previous time and place such as in Muhammad period of umma and Greek period of polis and transform them in to the context of the contemporary world today to achieve peace, justice, and harmony in the pluralistic society of the world and specifically in Indonesia. Both cases in the context of the world politics and the process of democratization in Indonesia, we know that there are a lot of challenges facing human civilization. As we always learn from Islam (Muhammad) and other religions that the act of self-discipline spiritually, and rationally, is the key to the real freedom, peace, and harmony. The biggest problem of politics today is the concept of identity that is too dangerous to be true. If we believe fully in this concept absolutely, then we are going to be selfcentered and disrespect the different because this political sameness is creating the narrow mind to homogenize people where in nature is different. That is why we need to be cautious about this new 'modern' concept.

Perhaps our weakness of this article is about less exploring the idea of the institution and its transformation. Additionally, we are trying to explain comprehensively in a simple way but it could be not cover everything. Most importantly, we are trying to see the complexity of these concepts and its challenge in the realm of global politics and Indonesian politics. We do more emphasize in the ethical and ontological universal values perspective as the software of the modern institution whether it is modern umma of Indonesia (democracy of umma), or cosmopolitan (global governance). Here, we find that umma is universal values that Madina community was just a model because umma concept is not the monopoly of Islam, but every nation-state in the world could be called as close to umma in the context of civilized community/society in contrast to the jahiliya (ignorant community/society).

\section{Literature}

[1]Beck, Ulrich "Ulrich Beck: Pioneer in Cosmopolitan Sociology and Risk Society," in Ulrich Beck's Scientific
Leadership Profile, ed. Hans Günter Brauch (Springer Cham Heidelberg New York Dordrecht London: Springer, 2014

[2]. Beck, Ulrich. "Cosmopolitanism as Imagined Communities of Global Risk." American Behavioral Scientist 55, no. 10 (2011)

[3]. Ramadan, Tariq. In the Footsteps of the Prophet: Lessons from the Life of Muhammad. New York; Oxford: Oxford University Press, 2007

[4]. Shani, Giorgio. "Toward a Post- Western Ir: The Umma, Khalsa Panth, and Critical International Relations Theory," International Studies Review 10, no. 4 (2008).

[5]. Patomaki, Heikki "Cosmological Sources of Critical Cosmopolitanism," Review of International Studies 36 (2010)

[6]. Moses, Jonathon W. "The Umma of Democracy," Security Dialogue 37, no. 4 (2006).

[7]. Ramadan, Tariq The Quest for Meaning: Developing a Philosophy of Pluralism (London: Allen Lane, Penguin group 2010 